\title{
Responsive predicates are question-embedding: Evidence from Estonian ${ }^{1}$ Tom ROBERTS - University of California, Santa Cruz
}

\begin{abstract}
The proper semantic treatment of the complements of Responsive Predicates (ResPs), those predicates which may embed either declarative or interrogative clauses, is a longstanding puzzle, given standard assumptions about complement selection. In order to avoid positing systematic polysemy for ResPs, typical treatments of ResP complements treat their arguments either as uniformly declarative-like (propositional) or interrogative-like (question). I shed new light on this question with novel data from Estonian, in which there are verbs think-like meanings with declarative complements and wonder-like meanings with interrogative complements. I argue that these verbs' meaning is fundamentally incompatible with a proposition-taking semantics for ResPs, and therefore a question-taking semantics is to be preferred.
\end{abstract}

Keywords: responsive predicates, embedded clauses, interrogatives, contemplation, Estonian.

\section{Introduction}

It is well-established that clausal-selecting predicates differ in the types of complements they permit. Rogative predicates (terminology after Lahiri 2002) like wonder and ask only permit interrogative complements, anti-rogative predicates like think and believe only permit declarative complements, and responsive predicates (ResPs) like know and say permit either type of complement. The three predicate classes are exemplified in (1).
a. Prudence thinks/believes $\{$ that $/ *$ why $\}$ wombats are herbivores.
Anti-rogative
b. Prudence wonders/asks $\{*$ that/why $\}$ wombats are herbivores.
Rogative
c. Prudence knows/says $\{$ that/why $\}$ wombats are herbivores.
Responsive

Clausal arguments are argued in large part to be s(emantically)-selected (Grimshaw, 1979; Pesetsky, 1982, 1991)-that is, a clause-taking predicate lexically imposes a requirement that its complement be of a particular semantic type. ResPs pose a problem for this view given the widely-held assumption that declarative clauses denote propositions and interrogative clauses denote sets of propositions. Unless ResPs are systematically polysemous, there is no simple way for it to embed these two different types of arguments-and if they are systematically polysemous, it remains to be seen why that should be the case.

One indication we may not want to stipulate the selectional behavior of such verbs directly into the lexicon as opposed to deriving their selectional restrictions from independent properties of their semantics is that this tripartite categorization is also attested cross-linguistically. For

\footnotetext{
${ }^{1}$ Thanks to Pranav Anand, Patrick Elliott, Donka Farkas, Valentine Hacquard, Jim McCloskey, Mark Norris, Kyle Rawlins, Deniz Rudin, Yasutada Sudo, Anne Tamm, and audiences at LASC 2017, CLS 53, and SuB 22 for helpful comments, suggestions, and insights at various stages of this project. Above all, suur aitäh to my Estonian informants, for their valuable ideas and willingness to entertain the many bizarre and occasionally indelicate scenarios I asked them to mõtlema: Rein Jüriado, Ann Kaer, Gaili Kalberg, Kristjan Eerik Kaseniit, Nele Kirt, Märten Padu, and Einar Treimann. Any errors are, of course, my own.
} 
instance, in Estonian, just as in English, there are indeed clausal-embedding verbs of all three selectional categories:
a. Kirsi usub, $\{$ et/*miks $\}$ lapsed on aias.
Kirsi believes that/why children are garden.INESS
'Kirsi believes that/*why the children are in the garden.'
b. Kirsi küsib, \{et/miks $\}$ lapsed on aias.
'Kirsi asks *that/why the children are in the garden.'
Anti-rogative
Kirsi teab, \{et/miks $\}$ lapsed on aias.
Rogative
c. Kirsi teab, $\{$ et/miks $\}$ lapsed on aias.
'Kirsi knows that/why the children are in the garden.'
Responsive

Indeed, far from being a quirk of English, the differential selectional behavior of clausalembedding predicates is observed in many languages: therefore, to the extent possible, a general solution is preferable. But how can we reconcile our assumptions about selection with the existence of responsive verbs like know?

\subsection{Prior solutions to the ResP puzzle}

The dominant approach to solving the ResP puzzle is to reduce all clausal complements of ResPs to the same type. One flavor of this tactic is the proposition-embedding account of ResPs, in which the meaning of interrogative complements is reduced to a proposition, which are taken to be the denotation of declarative clauses (Karttunen, 1977; Groenendijk and Stokhof, 1984; Heim, 1994; Dayal, 1996; Lahiri, 2002; Egré, 2008; Spector and Egré, 2015; Mayr, 2017: a.o.). While this approach captures the behavior of responsive predicates, the existence of antirogatives becomes mysterious, since it will be necessary to justify the exclusion of type-shifted interrogative complements on independent grounds.

The mirror-image approach is the question-embedding account, which reduces the meaning of a declarative clause to a question, a position articulated most completely by Uegaki (2016) (though see also Elliott et al., 2017). Uegaki's primary motivation for this approach comes from contrasts between anti-rogatives and ResPs with regards to their entailment patterns with content DP complements:
a. John believes the rumor that Mary left.
$\vDash$ John believes that Mary left.
b. John knows the rumor that Mary left.
$\not \models$ John knows that Mary left.

(Uegaki 2016: 626)

Uegaki argues that only a propositional-embedding predicate can yield the entailment in (3a), and if know were also embedding propositions, there would be no way to derive the contrast between (3a) and (3b). There is no way, he claims, for the rumor that Mary left to denote a proposition without yielding the entailment of (3b). The question-embedding approach to ResPs must also argue on independent grounds why any verb should be purely rogative.

A third option is to dispense with the assumption that declaratives and interrogatives denote 
different sorts of formal semantic objects to begin with, a treatment baked into frameworks like Inquisitive Semantics (Ciardelli et al., 2013; Theiler et al., 2016; Roelofsen, 2017; Roelofsen et al., to appear). Under such a view, the existence of ResPs is not only expected, but it is the default behavior of clausal-embedding verbs; the behavior of (anti-)rogatives must be derived on independent grounds. This option will not be considered in detail here, as the predictions it generates for ResPs are identical to the question-embedding perspective; both treat the denotation of any ResP complement clause as a set of propositions. Because this paper is only concerned with responsive predicates, it cannot adjudicate between this approach and a question-embedding approach. ${ }^{2}$

Ultimately, the treatment of ResPs should be empirically motivated: can we find ResPs whose meaning is fundamentally incompatible with one type of complement or another? In this paper, I will argue that the answer to this question is yes-and that the question-embedding semantics of ResPs is preferable-based on novel data from the Estonian verb mõtlema 'think, consider'. The basic fact which comprises the bulk of the argument is that motlema canonically signals that the attitude holder stands in a belief relation to an embedded declarative (4a), and an ignorance relation to the true answer to embedded interrogative (4b)-(4c):
a. Liis mõtleb, et sajab vihma.
Liis MÕTLEMA that falls rain
'Liis thinks that it's raining.'
b. Liis mõtleb, kas sajab vihma.
Liis MÕTLEMA Q falls rain
'Liis wonders whether it's raining.'
Liis MÕTLEMA where falls rain
'Liis wonders where it's raining.'
c. Liis mõtleb, kus sajab vihma.

The chimerical behavior of mõtlema, in which its interpretation is fundamentally dependent on the type of its complement, is superficially surprising. However, I argue that mottema provides evidence in favor of the question-embedding account. In a nutshell, mõtlema indicates that an individual is thinking about something. That something cannot be plausibly thought of as being propositional.

The paper is structured as follows. Section 2 discusses properties of the motlema and argues that its behavior cannot be fully capture by a proposition-taking semantics. Section 3 introduces the idea of a contemplation state and argues that môtlema can be profitably analyzed as simply situating an embedded question in an attitude holder's contemplation state. Section 4 derives the interpretation of mõtlema in context from its denotation and general pragmatic principles. Section 5 concludes.

\footnotetext{
${ }^{2}$ Groenendijk and Stokhof $(1984,1989)$ also treat clausal complements as uniform, but, for them, the denotation of embedded questions is propositional.
} 


\section{The case of Estonian mõtlema}

What is striking is that mõtlema seems to convey radically different attitudes-paraphrasable roughly as think and wonder-depending on the type of its complement. A natural reaction to examples like (4) would be to simply assume that there are two different lexical items who share the same phonological form of mottema: one which takes a declarative complement and one which takes an interrogative.

While this approach could quite possibly achieve descriptive adequacy, I believe it falls short of explaining the pattern for at least two reasons. The first is that motlema is not alone in this kind of behavior even in Estonian: similar patterns can be observed with môtisklema 'consider', vaatlema 'observe,' and meelisklema 'muse'.

(5) Mõtisklen, et kuidas teie ärimudel skaleeruvale startupile contemplate.1SG that how your business.model scalable.ALL startup.ALL vastab. satisfies.3SG

'I'm wondering how your business model succeeds as a scalable startup.'

(6) Autor vaatleb, kas põgenedes on võimalik tagasi jõuda.

author observes $\mathrm{Q}$ escape.PL.INESS is possible back be.able.INF

'The author looks at whether it is possible to escape.'

Furthermore, the Finnish verb miettiä, a presumed cognate of môtlema, displays the same sort of behavior, suggesting that the generalizations to be derived about mottema can at least be extended to neighboring languages:
a. Mietin, olisi=ko nyt hyvä hetki myydä.
think.1SG would.be=Q now good moment sell.INF
'I wonder whether now would be a good time to sell.'
b. Mietin, että nyt voisi olla hyvä hetki myydä. think.1SG that now might be.INF good moment sell.INF 'I think that now might be a good time to sell.'

The second argument against a bifurcated lexical approach comes from conjunction. A declarative and interrogative complement can be felicitously conjoined under a single use of mótlema with a sufficiently rich context. In these instances, the interpreted attitudes are equivalent to each clausal complement with mõtlema in isolation.

(8) Context: Your computer won't turn on. You think the problem is the hard drive, but you aren't completely sure so you take it to a computer repair shop. You also don't know if your computer is beyond the point of saving. Later, you tell your friend:

\footnotetext{
${ }^{3}$ http: //opleht.ee/2014/03/kolmeteistkumnenda-aasta-kolmteist-parimat-2/

${ }^{4}$ Thank you to an anonymous reviewer for these examples.
} 
Ma mõtlen, et mu kõvaketas on katki ja kas nad saavad selle korda. I MÕTLEMA that my hard.disk is broken and Q they can.3PL it.GEN fix.INF 'I think that my HDD is broken and I wonder if they can fix it.'

These two uses of motlema in (4) seem at odds with one another, given that belief and ignorance are contradictory. While belief is doxastic commitment on the part of the attitude holder towards a proposition $p$, ignorance entails the absence of any such commitment to $p$ or any of its alternatives. Cross-linguistically, verbs that encode representational belief (in the sense of Hintikka 1962) when taking a declarative complement typically do not also permit interrogative complements (Egré, 2008; Spector and Egré, 2015) modulo doxastic factives like know.

Therefore, an analysis of mõtlema has two major desiderata: one, it needs to treat clausal complements in a unified way, and two, it needs to derive the interpretation of mõtlema with different complements. In pursuit of these goals, I turn now to consider what, exactly, mõtlema can mean in different contexts.

\subsection{Interpretation with embedded declaratives}

Out of the blue, motlema utterances with declarative complements are interpreted simply as belief ascriptions:

(9) Nad mõtlevad, et valijad on lambad. they MÕTLEMA that voters are sheep 'They think that voters are sheep.'

However, mõtlema differs from the ResP know (and its Estonian counterpart teadma), in that it is nonfactive, despite the fact that both verbs can be used to ascribe a belief to an attitude holder. Hence, although the but-clause in (10) is judged infelicitous because in contradicts the presupposition introduced by know, its correspondent in (11) is not:

(10) Ambrose knows that it is raining, \#but it isn't raining.

(11) Liis mõtleb, et sajab vihma, aga ei saja.

Liis MÕTLEMA that falls rain but NEG fall.NEG

'Liis thinks that it's raining, but it isn't raining.'

Mõtlema may also be used to attribute beliefs to third parties with whom the speaker disagrees: in (12), the speaker indicates that Aarne has a belief that Helsinki is in Sweden, and follow up this claim with an explicit declaration that the attitude holder is incorrect. In these cases, mõtlema behaves similarly to well-studied verbs of representational belief like think and believe, or their approximate Estonian counterparts, arvama and uskuma.

Aarne mõtleb, et Helsingi on Rootsis. Ta on nii loll!

Aarne MõTlEma that Helsinki is Sweden.INESS he is so dumb

'Aarne thinks that Helsinki is in Sweden. He's so dumb!' 
Unlike arvama, mõtlema may be used to introduce beliefs not actually held by the attitude holder in the world of evaluation, but rather hypothetical scenarios she is entertaining. For instance, in (13), the speaker is explicit about her commitment to dinosaurs not being alive, but nonetheless, she is considering the counterfactual situations in which they are indeed alive.

\section{Context: I am discussing with my friend what life would be like if an asteroid had not} collided with the earth at the end of the late Cretaceous period.

Ma $\{$ mõtlen/\#arvan $\}$, et dinosaurused on ikka elus, kuigi ma tean, et ei I MÕTLEMA/think that dinosaurs are still alive although I know that NEG ole.

be.NEG

'I'm thinking about dinosaurs still being alive, even though I know that they aren't.'

In all, the interpretation of motlema with a propositional argument $p$ is dependent on the speaker's assessment of the attitude holder's doxastic state. If the attitude holder is assumed to hold a belief that $p$, mõtlema can felicitously be used to describe this belief. However, if the context is such that the speaker's beliefs contradict $p$, then mottlema receives an imaginal interpretation. These generalizations are summarized in (14).

\begin{tabular}{|c|c|c|c|}
\hline & $D O X_{x}^{w} \subseteq p$ & $D O X_{x}^{w} \cap p \neq \varnothing$ & $D O X_{x}^{w} \cap p=\varnothing$ \\
\hline$x$ mõtlema $p$ & ' $\mathrm{x}$ thinks p' & ' $x$ thinks about the possibility that $p$ ' & ' $\mathrm{x}$ imagines $\mathrm{p}$ ' \\
\hline
\end{tabular}

\subsection{Interpretation with embedded interrogatives}

Unlike with declarative complements, motlema with an embedded interrogative typically has an inquisitive flavor. For instance, a speaker could felicitously utter (15) in a context in which she is not expecting any company and there is a knock by an unknown person at the door:

$$
\begin{aligned}
& \text { Ma mõtlen, kes ukse taga on. } \\
& \text { I think.1 SG who door.GEN behind is } \\
& \text { 'I wonder who is at the door.' }
\end{aligned}
$$

Given that môtlema does not seem to entail commitment with an embedded declarative, it is worth asking ourselves whether it entails agnosticism to the true answer to an embedded interrogative. As it turns out, the answer is no, given a sufficiently rich context.

(16) Context: Liis hears a knock at the door. She was expecting her friend Kirsi to come over, but she fantasizes for just a moment all the famous celebrities who could be showing up instead.

Liis mõtleb, kes ukse taga on, kuigi ta teab, et on Kirsi.

Liis thinks who door.GEN behind is although she knows that is Kirsi 
'Liis is thinking about who is at the door, even though she knows, that it is Kirsi.'

Again, just as with embedded declaratives, the interpretation of mõtlema with an embedded interrogatives depends on the attitude holder's doxastic state: if she is agnostic about the true answer to $q$, mottlema is much like English wonder, but if she is not, then the question is treated as 'musing' or 'hypothetical'.

\begin{tabular}{lcc} 
Interpretations of $x$ motlema $q$ & \\
& $\exists p_{n} \in q\left[D O X_{x}^{w} \subseteq p_{n}\right]$ & $\nexists p_{n} \in q\left[D O X_{x}^{w} \subseteq p_{n}\right]$ \\
\hline$x$ mõtlema $q\left(q=\left\{p_{1}, p_{2}, \ldots\right\}\right)$ & 'x thinks about q' & 'x wonders q' \\
\hline
\end{tabular}

\subsection{Challenges for Proposition-Taking Theories of ResPs}

The two main reductive approaches for the semantics of ResPs, as discussed in $\S 1$, are to treat all their clausal complements as proposition-denoting or question-denoting. While in principle the proposition-denoting story is appealing, as it makes the simplifying reduction from questions to propositions as opposed to the complexifying operation in the other direction, mõtlema is simply not compatible with a propositional semantics when it has an interrogative complement.

The motivations for the proposition-taking analysis of ResPs are, at first brush, incredibly appealing. George (2011) and Spector and Egré (2015) articulate a key intuition about the relationship between the meanings of responsive predicates with declarative complements (18a) and interrogative complements (18b). Namely, that in worlds where the handmaiden is the true chalice thief, (18a) and (18b) are essentially equivalent:

(18) a. Gertrude knows that the handmaiden stole the chalice.

b. Gertrude knows who stole the chalice.

To put it more plainly, to know an embedded interrogative $q$ means, for some $p$ that is the true answer to $q$, to be in a know-relationship to $p$. This straightforward propositional meaning for interrogative complements does not hold for rogative verbs like ask, which do not similarly encode a relationship between an individual (namely the 'attitude holder') and a proposition.

a. Agatha asked what Vlad added to the tripe.

b. *Agatha asked that Vlad added polonium to the tripe.

Under this view, ask is a bonafide question-taking verb, but know selects propositions. In Estonian, if we consider only the semantics of teadma 'know', this pattern holds up: teadma $q$ is interpreted as teadma $p$ for some $p$ which is an answer to $q$ :

(20) Eestlased teavad, mis kohv on Ladina-Ameerikast.

Estonians know what coffee is Latin-America.ELA

'Estonians know which coffee is Latin American.' 


\section{$\rightarrow \exists \mathrm{p}[\mathrm{p}=$ ' $\mathrm{x}$ coffee is Latin American' and know(Estonians, $\mathrm{p}))]$}

For Spector and Egré (2015), these observations are taken as evidence that ResPs take propositional complements. However, the pattern is not the same for mõtlema: not only does mottema $q$ not entail motlema $p$ for any $p$ which is an answer to $q$, it implicates ignorance on the part of the attitude holder:

Liis mõtleb, kes ukse taga on.

Liis thinks who door.GEN behind is

'Liis wonders who's at the door.'

$\rightsquigarrow$ Liis doesn't know who's at the door.

While the propositional complement analysis correctly predicts that responsive predicates can embed both declaratives and interrogatives, this is a feature shared with the question-embedding account. In addition to the burden of coming up with a propositional meaning for the interrogative complement in (21), the account faces two chief explanatory hurdles. The first is that there must be an operator or other mechanism which does the clausal type-shifting of interrogative ResP complements to begin with, which in the absence of independent motivation must be stipulated. The second is that additional stipulations are required to explain the ungrammatically of sentences like (22), where an anti-rogative verb appears with an embedded interrogative:

*Shirley thinks whether she will win the lottery.

If type-shifting of embedded interrogatives is an available option for ResP complements, an independent reason for ruling out sentences like (22) is required. Accounts vary on how precisely they achieve this, though many problems arise from the various approaches. While an examination of each of these approaches is outside the scope of this paper, more extensive argumentation about the inadequacies of a question-to-proposition complement approach can be found in Uegaki (2016).

\section{Mõtlema as a question-embedding verb}

In order to capture the "contemplative" nature of a môtlema utterance, I propose that contemplatives like môtlema straightforwardly denote a relationship between an attitude holder and what I term her CONTEMPLATION STATE, and as I will argue, this denotation captures mõtlema's intuitive range of meanings combined with relatively fundamental pragmatic principles.

\subsection{Contemplation states}

Attitude verbs specify relationships between attitude holders and propositions in a variety of different ways. For instance, some verbs make reference to an individual's beliefs, such as the many attitude verbs which relate propositions to the doxastic states of individuals like think and believe (Hintikka, 1962; Kratzer, 2006; Anand and Hacquard, 2013, 2014: inter alia). Others, like want, relate an attitude holder to her desires. 
It is a question of serious theoretical importance which attitudes linguistic expressions are sensitive to. The intuition with motlema utterances is that they are used to describe the content of what one is thinking about, rather than what they are committed to. It is easy, for instance, for one to think about both the way the world is and the ways it could be, and compare those side by side. I define this imaginal space as a 'contemplation state' of an individual as in (23).

A contemplation state of an individual $x \operatorname{CONTEM}_{x}^{w}$ is the set of pairs of sets of worlds and issues (sets of sets of worlds) $\left\{\left\langle\mathrm{W}_{1}, \mathrm{Q}_{1}\right\rangle,\left\langle\mathrm{W}_{2}, \mathrm{Q}_{2}\right\rangle, \ldots,\left\langle\mathrm{W}_{n}, \mathrm{Q}_{n}\right\rangle\right\}$ such that for all $\left\langle\mathrm{Q}_{m}, \mathrm{~W}_{m}\right\rangle, \mathrm{Q}_{m}$ is a partition of $\mathrm{W}_{m}$ and $\mathrm{Q}_{m}$ is under active consideration by $x$ in $w$.

In prose, a contemplation state consists of pairs of sets of worlds of evaluation $\mathrm{W}$ and ways of carving up that set of worlds Q, much like the partition semantics for questions of (Groenendijk and Stokhof, 1984). A contemplation state is, in effect, an attitude holder's 'mental workspace.' The precise W may vary: a potential default W might be the set of world's compatible with x's beliefs, since frequently people are tasked with situating themselves in (and uncovering truths about) the actual world modeled by their beliefs. There are, of course, many possible partitions over the same domain of worlds; and as the definition is formulated here, multiple questions may in principle be in an agent's contemplation state simultaneously. ${ }^{5}$

\subsection{Mõtlema and contemplation}

With the definition of contemplation in mind, I propose that môtlema straightforwardly denotes a relationship between an attitude holder and an embedded question, and militates that that question forms a partition in the attitude holder's contemplation state. The formal denotation for môtlema is given in (24).

$$
\llbracket m \tilde{o t l e m a} \rrbracket^{w}=\lambda \mathrm{x}_{e} \cdot \lambda \mathrm{Q}_{\langle s t, t\rangle} \cdot \exists \mathrm{W}_{s t}\left[\langle\mathrm{~W}, \mathrm{Q}\rangle \in \operatorname{CONTEM}_{x}\right]
$$

Informally, this denotation captures the intuition that mõtlema is used to indicate that an individual is thinking about a question: but while this question is under active consideration, the attitude holder need not have any other attitude in particular toward it.

Given the denotation of a contemplative verb complement as that of a question, it is necessary to invoke some sort of type-shifting operation for the complements that superficially appear to be declaratives. Following Uegaki (2016), I utilize the type-shifting operator ID, which takes a proposition as an argument and returns the singleton set containing that proposition. For independent evidence motivating the existence of this sort of type-shifting operator, see Partee

\footnotetext{
${ }^{5}$ These questions may even be partitions of different W's, as in examples like the following:

(i) Context: I invited John and Mary, two professors, for dinner. Only one said they would come, but I can't remember which, but I know that they don't have the same taste in food.

I am contemplating which professor is coming to dinner and what I will cook.
}

It is not difficult to imagine that the speaker's space of possible meals to cook is at least partially dependent on which professor will be in attendance. Should we involve a contemplation state in the meaning of the English verb contemplate, the relevant questions may partition different sets of worlds. 
(1986). The denotation of ID is given in (25).

$$
\llbracket \mathrm{ID} \rrbracket^{w}=\lambda \mathrm{p} \cdot[\lambda \mathrm{q} \cdot \mathrm{q}=\mathrm{p}]
$$

What ID allows us to do is pair mottema with embedded declaratives without a type mismtch. If mõtlema $Q$ implicates ignorance, it may not be immediately obvious why mõtlema $P$ does not generate the same implicature; the derivation of different interpretations of mõtlema will be elaborated in Section 4.

\subsection{Comparison with Rawlins (2013)}

The idea of non-representational ways of reasoning about alternatives is not new. Rawlins (2013), for instance, references the related but distinct concept of abstract 'content.' Content, in the sense of Hacquard $(2006,2010)$, is a property of eventualities: the content of a belief eventuality, for instance, is the intersection of all of the propositions that the relevant individual believes.

Rawlins's notion of content is slightly different. For him, content is a curried equivalence relation on worlds, which partitions $\mathbb{W}$ into sets of worlds which satisfy this equivalence relation, intuitively partition the space of possible worlds as a set of alternatives.

Unlike Rawlins's content, the idea of contemplation introduced here is inherently cognitive and agent-oriented, like belief or desire. The primary empirical focus of Rawlins is English PPs headed by the preposition about, which is highly promiscuous in the sorts of complements it may appear in. The motivation of contemplation as I have defined it is a relatively small class of attitude verbs which resist analysis as proposition-embedding despite their frequent use in representational contexts.

Rawlins proposes that attitude predicates like think denote content-bearing properties of eventualities in the vein of Kratzer (2006) and Moulton (2009). But a reason we might wish to have a distinct notion of contemplation apart from content is precisely the fact that we see verbs like môtlema and contemplate, which appear with declarative and interrogative complements without the crutch of a content-selecting PP head like about.

As for why not just assume that mõtlema takes content-complements, note also that whereas questions and NPs may be the complement of about, propositions may not. So the types of semantic object that may constitute an argument of an Estonian contemplative versus about may also differ in a more ontologically robust way ${ }^{6}$ :

${ }^{6}$ It is also worth mentioning that NPs marked with allative case in Estonian are also permissible as complements of mõtlema:

(i) Ta mõtles Suurele Vennale.

he MÕTLEMA.PAST big.ALL brother.ALL

'He thought about Big Brother.'

It might be tempting for this reason to throw up our hands and simply treat môtlema as think and the allative case as about here-however, the allative case marking is not licensed in other complements of mõtlema, nor does 
*Joyce thought about (that) it was raining.

In short, Rawlins's content and my contemplation states broadly share similarities in describing ontologically underspecified notions of largely conceptual semantic objects as partitions over sets of worlds. Contemplation is fundamentally attitudinal: a tool of characterizing particular mental states, namely the internal consideration of a question which may or may not be resolved. Content is also a general way of describing the content of an attitude as an equivalence relation over sets of worlds. One way in which contemplation is perhaps more flexible is in the ability of different elements in the contemplation state to partition different sets of worlds with different contextual domain restrictions; it is not clear how such cases might be tackled in Rawlins's system.

\subsection{Comparison with Ciardelli and Roelofsen (2015)}

The approach sketched here also overlaps in many ways with Ciardelli and Roelofsen's (2015) extension of epistemic logic, in which agents can both know information and entertain issues. In particular, there is some similarity between contemplation and C\&R's entertain modality $\mathrm{E}_{a}$, which has the following semantics:

$$
\text { Semantics of } E_{a}(\mathrm{C} \& \mathrm{R} 2015: 3.4)
$$

Let $M$ be an inquisitive model and $s$ be an information state in $M$. $\langle M, s\rangle \models E_{a} \varphi \Leftrightarrow$ for any $w \in s$ and for any $t \in \Sigma_{a}(w),\langle M, t\rangle \models \varphi$

In other words, an agent $a$ entertains $\varphi$ iff in each world $w$ in her information state, every resolution of her inquisitive state supports $\varphi$. When $\varphi$ is interrogative, entertainment is quite similar to contemplation: the speaker declares a particular issue to be settled by resolutions of her inquisitive state.

However, when $\varphi$ is a declarative, $E_{a} \varphi$ entails knowledge of $\varphi$, since the inquisitive state with respect to $\varphi$ is already resolved.

The crucial difference is that this knowledge entailment is not present for contemplation, which merely asserts that an issue is being considered by an agent, irrespective of her actual beliefs. This is evidenced by 'faultless retraction' cases in Estonian with mõtlema, as in the now-familiar dinosaur example:

(28) Ma mõtlen, et dinosaurused on ikka elus, kuigi ma tean, et ei ole.

I think that dinosaurs are still alive although I know that NEG be.NEG

'I'm thinking about dinosaurs still being alive, even though I know they're not.'

If mõtlema has the denotation in (24), (28) is not contradictory: the speaker's contemplation of

this observation help us understand why mõtlema can embed declaratives but about cannot. But the connection certainly merits further investigation. 
the existence of dinosaurs may or may not match her true beliefs. But if mõtlema denotes $E_{a}$, (28) is contradictory: the speaker indicates she believes both that dinosaurs are still alive and that they are not alive.

We can rectify this contradiction if each clause is evaluated dynamically relative to a different information state: In the mõtlema-clause, the speaker behaves as if she is adopting an information state in which dinosaurs exist. In the second clause, the speaker reveals that her information state in $w_{0}$ is one in which dinosaurs do not exist.

But, if an information state-shifting mechanism is in principle a possibility, we have no reason to expect the infelicitous English example in (29) should be anomalous:

(29) \#I wonder why dinosaurs are still alive, even though I know they aren't.

While the CONTEM modality and the $E$ modality are similar both in nature and intent, the fact that $E_{a} \varphi$ entails $K_{a} \varphi$ in C\&R's logic necessitates additional mechanisms to correctly predict the felicity of faultless retraction with motlema.

\section{Pragmatic derivation of meaning with mõtlema}

\subsection{Embedded interrogatives}

Recall one of the central puzzles presented in this paper: how do verbs like môtlema yield such different interpretations dependent solely upon the type of their complement? The semantics here involves an agent weighing a set of alternatives-different possible resolutions to a question-against one another. If a mõtlema-sentence expresses a purely mental calculus about an agent's evaluation of alternatives: why should such a sentence indicate anything about 'wondering' or 'ignorance'?

Upon closer investigation, that mõtlema with an embedded interrogative canonically implicates ignorance is unsurprising given its semantics. If a person is weighing different alternative answers to a question against one another, the most natural reason for them to do so is that they are seeking the true answer to the question. While people can and do 'muse' about questions regularly, the precise reason for them doing so becomes much clearer in context. If a knock is heard at the door, a speaker who utters (28) can reasonably be understood to be ignorant of the true identity of the knocker. If they did in fact know who was at the door, it would be quite bizarre for them to indicate they were merely thinking about the possible alternatives, because it would not be a sufficiently informative reaction to the situation, a Quantity violation in the spirit of Grice (1975).

We can generalize this intuition: in any case where a mõtlema $P$ alternative to a mõtlema $Q$ utterance could have been cooperatively uttered by the speaker to further a conversational goal, the môtlema $P$ version will be more informative. To illustrate, let us revisit the now familiar case of (4), reprinted below as (30), with the attitude holder's contemplation state: 
a. Liis mõtleb, et sajab vihma.

Liis thinks that falls rain

'Liis thinks that it's raining.'

CONTEM $_{\text {Liis }}=\left\langle\{\right.$ it is raining $\left.\}, \mathrm{W}_{1}\right\rangle$

b. Liis mõtleb, kas sajab vihma.

Liis thinks $Q$ falls rain

'Liis wonders whether it's raining.'

CONTEM $_{\text {Liis }}=\left\langle\{\right.$ it is raining, it is not raining $\left.\}, \mathrm{W}_{2}\right\rangle$

In both cases, the W-the set of worlds under consideration-is taken by default to be the set of worlds compatible with Liis's beliefs in the absence of evidence to the contrary. In the case of (30a), Liis is only considering worlds in which it is raining, whereas (30b) includes both rain-worlds and non-rain-worlds. Holding all of Liis's other beliefs constant, the set of worlds in Liis's contemplation state in (30b) is a superset of those in (30a).

Because (30b) allows for there to be both rain-worlds and non-rain-worlds in Liis's contemplation state-and again, these worlds are those compatible with Liis's beliefs. Because there is the additional possibility of non-rain-worlds in Liis's contemplation state with the embedded interrogative but not the embedded declarative, (30a) is a strictly more informative utterance. If only the proposition 'it is raining' is compatible with Liis's doxastic state, there is a pragmatic preference for uttering (30a) over (30b).

There are cases where môtlema $Q$ does not license an ignorance inference, but these are precisely the sort of cases where the 'contemplative' nature of an agent is at-issue.

Context: Siim is reading a book about Estonian history. It got him thinking about all the reasons there were for Estonia to lose the war with Russia in the 1500s.

Siim mõtleb, miks Eesti kaotas sõja.

Siim thinks why Estonia lost war

'Siim is thinking about why Estonia lost the war.'

In context, Siim knows full well why Estonia lost the war: for the reasons delineated in his book. Nonetheless, the topic sparked his imagination, and all of those reasons-as well as possible alternatives-are now a topic of active consideration for him. He is not ignorant as to why the war was lost, but merely a curious pontificator. While mõtlema can implicate ignorance towards an embedded question, this arises from the pragmatics of contemplation, rather than an entailment in the lexical entry for mõtlema.

This is a different route to agnosticism than the one taken by true anti-rogatives. For instance, (Uegaki, 2016) takes anti-rogatives like wonder to presuppose ignorance: i.e., that at least two of the alternatives in the embedded interrogative are live possibilities for the attitude holder. This is cashed out as a presupposition of these predicates that the cardinality of their complement is at least 2 .

【wonder/ask/inquire $\rrbracket^{w}(Q)(x)$ is defined only if the following proposition is compatible 
with x’s beliefs: $\lambda w . \exists p \in Q[p(w)] \wedge \exists p \in Q[\neg p(w)]$

(Uegaki 2016: 647)

While Uegaki's presupposition captures the facts nicely for wonder, it does not make quite the right predictions for all anti-rogatives, like Estonian küsima 'ask'. Consider the following sentence, uttered to describe a pedagogical context:

Õpetaja küsib, kas [p] ahtushäälik on.

teacher asks Q fricative is

'The teacher asks whether $[\mathrm{p}]$ is a fricative.'

Presumably the teacher actually knows the answer to the embedded question; (33) simply describes an inquisitive speech act he is performing in order to quiz students on their knowledge. By the letter of Uegaki's definition, this renders the presupposition of küsima unsatisfied. What is crucial is that the teacher is behaving as though he does not know the answer to the question in some relevant way. Therefore, I propose a small tweak to Uegaki's definition, bolded:

【wonder/ask/inquire $\rrbracket^{w}(Q)(x)$ is defined only if the following proposition is compatible with what $\mathbf{x}$ presents to be x's beliefs: $\lambda w . \exists p \in Q[p(w)] \wedge \exists p \in Q[\neg p(w)]$

Since wonder can only take questions as complements, this requires that the subject is 'wondering' about at least two possible alternatives. Even if the type-shifted version of an embedded interrogative is available to wonder, a question-version of a declarative sentence contains only one proposition. While I hesitate to make a direct comparison between motlema and wonder per se, suffice it to say that mottema has no such presupposition of ignorance-which may, in turn, connect to its freer range of permissible complements than wonder.

\subsection{Embedded declaratives}

We have seen many uses of motlema paired with a declarative complement which most naturally generates a belief interpretation, despite the fact that nothing about the proposed contemplative semantics for mõtlema entails such an interpretation. To see how belief interpretations may naturally arise, consider the following:

Mu kass mõtleb, et pitsapoiss on mu omanik. my cat MÕTLEMA that pizza.boy is my owner 'My cat thinks that the pizza boy is my owner.'

In a typical situation, no ignorance of any sort is implicated by uttering (35): the speaker is intending to (anthropomorphically) ascribe a belief to his cat, namely the belief that the pizza boy is the speaker's owner (the pizza boy brings the speaker food, the ostensible mark of ownership).

Why should this be the case? Note that a mõtlema $p$ sentence requires its complement to first be type-shifted into a set of propositions through application of ID. The attitude holder is then taken to be contemplating a single-alternative question, which constitutes a trivial partition over 
the contextually relevant set of worlds.

For similar reasons to mõtlema $q$ implicating ignorance, mõtlema $p$ implicates belief. If an agent only has one alternative under consideration, a natural inference is that that alternative is the most viable candidate for the actual world, as far as the agent is concerned. Were there to be multiple candidates for true resolutions to a particular question under discussion (with respect to some agent's epistemic state), it would be misleading to utter môtlema $p$, because the $\neg \mathrm{P}$ candidates are not mentioned. In normal circumstances, then, the speaker is taken to be asserting, indirectly, information about an agent's beliefs. In the case of (35), the speaker emphasizes that his cat is only considering the alternative where the pizza boy is the speaker's owner, rather than any other possible state of affairs.

This indirect method of belief ascription also naturally carries the implication that the purported belief in $\mathrm{P}$ is somehow 'weaker' than total commitment. While describing beliefs with mõtlema is frequent in naturally occurring speech, there exist other belief verbs like arvama, uskuma, and teadma which lexically encode this belief. Because alternative ways of describing belief that entail that belief are available, the use of belief-implicating mõtlema is weaker by comparison. In effect, there is pragmatic competition between different verbs which can functionally be used to ascribe belief.

This line of thinking makes empirically testable predictions. For instance, consider the case of predicates of personal taste. When a PPT under a belief verb, the understood interpretation is that the 'judge' against whom the truth of the embedded predicate (following Stephenson (2007)) is evaluated is the attitude holder. In the intended interpretation of (36), the speaker's sister is the one who judges chocolate to be delicious. There is a felicitous use of motlema here, under the somewhat anomalous reading where the speaker's sister is asserting chocolate to be delicious as an objective truth, rather than merely her opinion, deriving the anomalous interpretation that she intends to project her opinion by fiat:

$$
\begin{aligned}
& \text { Mu õde }\{\text { arvab/\#mõtleb }\} \text {, et šokolaad on maitsev. } \\
& \text { my sister thinks that chocolate is delicious } \\
& \text { 'My sister thinks that chocolate is delicious.' }
\end{aligned}
$$

A speaker's commitment to her belief in a taste predicate must be total, under the assumption that taste predicates require a 'judge' to be semantically evaluated (Stephenson, 2007). Thus, if a commitment-entailing verb exists in the lexicon, ascribing a taste predicate belief to an individual should require the use of such a verb rather than a weaker, commitment-implicating verb like mõtlema.

Along similar lines, in cases where a speaker may intentionally wish to convey their relative lack of commitment, mõtlema should be preferable to arvama. This is indeed borne out. Simons (2007) points out that verbs like think can be used as not-at-issue matrix verbs in cases where speakers wish to distance themselves from commitment to an embedded $p$ or indicate the weakness of their evidence for $p$. Should this be true, mõtlema is predicted to be preferred to arvama in cases where speakers intend to hedge. This is borne out in (37). 
Context: My coworker asks where Mary is. I heard a rumor that she was on vacation in Boston, but I don't really know her well enough to be really sure.

Ma $\{$ mõtlen/?arvan\}, et Mary on Bostonis.

I think that Mary is Boston.INESS

'I think that Mary is in Boston.'

If a speaker uses arvama in (37), they indicate they have good evidence for knowing Mary's whereabouts, rather than hearsay or conjecture which might negatively impact their confidence in the assertion. When compared side by side in the same context, arvama is always judged to indicate that the attitude holder has greater commitment towards an embedded proposition than does mõtlema.

It is important, however, to keep in mind that the implicit belief associated with mõtlema is defeasible in a sufficiently rich context. While all else being equal, an utterance of mottema $p$ would be likely to be understood as a belief report, in a context in which my beliefs are clearly contrary to that of the proposition that would be denoted by an embedded declarative, mótlema can be used instead to indicate that I am hypothetically entertaining that proposition, as in the example reprinted below:

\section{Context: I am discussing with my friend what life would be like if an asteroid had not} collided with the earth at the end of the late Cretaceous period.

Ma $\{$ mõtlen/\#arvan\}, et dinosaurused on ikka elus, kuigi ma tean, et ei I MÕTLEMA/think that dinosaurs are still alive although I know that NEG ole.

be.NEG

'I'm thinking about dinosaurs still being alive, even though I know that they aren't.'

\section{Conclusion}

In this paper, I have argued for an analysis of the superficially responsive Estonian verb mõtlema in which its surprising interpretative sensitivity to the type of its complement follows straightforwardly from a sufficiently bleached semantics and general pragmatic principles. Furthermore, the incompatibility of mõtlema's interrogative complements with propositional interpretations suggest that analyses of responsive predicates which uniformly treat their complements as propositions cannot account for the behavior of at least some ResPs. And while the account presented here maintains the assumption that declarative and interrogative clauses denote different types (à la Uegaki, 2016), it could just as easily fit into the framework of (Theiler et al., 2016), who argue on independent grounds for a uniform typing of clausal complements.

In developing a semantics for mõtlema, also introduced a new type of attitude, contemplation, which broadly concerns an individual's mental workspace, and offers some empirical advantages over related proposals. The idea of contemplation spaces may also be useful in analyzing clauses which serve as the complements of verbs like contemplate in English, or even those which are complements of prepositions like about. If contemplation is indeed an ontological 
primitive to which at least mõtlema is sensitive, we would expect other languages to lexically encode information about contemplation states as well.

Ultimately, however we choose to represent clausal complements, an ideal big-picture account of clausal-embedding verbs would be able to derive their selectional behavior from independent properties of their lexical semantics. However, in order to push this idea to the limit, continued close investigation of these verbs in a wide variety of languages is absolutely essential.

\section{References}

Anand, P. and V. Hacquard (2013). Epistemics and attitudes. Semantics \& Pragmatics 6(8), $1-59$.

Anand, P. and V. Hacquard (2014). Factivity, belief and discourse. In L. Crnič and U. Sauerland (Eds.), The Art and Craft of Semantics: A Festschrift for Irene Heim, Volume 1, pp. 69-90. Cambridge, MA: MIT Working Papers in Linguistics.

Ciardelli, I., J. Groenendijk, and F. Roelofsen (2013). Inquisitive semantics: A new notion of meaning. Language and Linguistics Compass 7(9), 459-476.

Ciardelli, I. and F. Roelofsen (2015). Inquisitive dynamic epistemic logic. Synthese 192(6), 1643-1687.

Dayal, V. (1996). Locality in wh-quantification: questions and relative clauses in Hindi. Kluwer Academic Publishers.

Egré, P. (2008). Question-Embedding and Factivity. Grazer Philosophische Studien 77(1), 85-125.

Elliott, P. D., N. Klinedinst, Y. Sudo, and W. Uegaki (2017). Predicates of relevance and theories of question embedding. Journal of Semantics 34(3), 547-554.

George, B. R. (2011). Question embedding and the semantics of answers. Ph. D. thesis, UCLA.

Grice, P. (1975). Logic and Conversation. In P. Cole and J. Morgan (Eds.), Syntax and Semantics 3: Speech Acts.

Grimshaw, J. (1979). Complement selection and the lexicon. Linguistic Inquiry 10(2), 279326.

Groenendijk, J. and M. Stokhof (1984). Studies on the Semantics of Questions and the Pragmatics of Answers. Ph. D. thesis, University of Amsterdam.

Groenendijk, J. and M. Stokhof (1989). Type-shifting rules and the semantics of interrogatives. In G. Chierchia, B. H. Partee, and R. Turner (Eds.), Properties, Types, and Meanings, Vol. 2: Semantic Issues, pp. 21-68. Dordrecht: Kluwer.

Hacquard, V. (2006). Aspects of Modality. Ph. D. thesis, Massachusetts Institute of Technology.

Hacquard, V. (2010). On the event relativity of modal auxiliaries. Natural Language Semantics 18, 79-114.

Heim, I. (1994). Interrogative semantics and Karttunen's semantics for know. In R. Buchalla and A. Mittwoch (Eds.), The Proceedings of the Ninth Annual Conference and the Workshop on Discourse of the Israel Association for Theoretical Linguistics, Academon, Jerusalem.

Hintikka, J. (1962). Knowledge and Belief. Cornell University Press.

Karttunen, L. (1977). Syntax and semantics of questions. Linguistics and Philosophy 1(1), 3-44.

Kratzer, A. (2006). Decomposing attitude verbs. Talk given in honor of Anita Mittwoch, the 
Hebrew University of Jerusalem.

Lahiri, U. (2002). Questions and Answers in Embedded Contexts. Oxford Studies in Theoretical Linguistics.

Mayr, C. (2017). Predicting polar question embedding. In Proceedings of Sinn und Bedeutung 21, pp. 1-28.

Moulton, K. (2009). Natural Selection and the Syntax of Clausal Complementation. Ph. D. thesis, UMass Amherst.

Partee, B. (1986). Noun phrase interpretation and type-shifting principles. In J. Groenendijk, D. de Jongh, and M. Stokhof (Eds.), Studies in Discourse Representation Theory and the Theory of Generalized Quantifiers, pp. 115-143. Dordrecht: Foris Publications.

Pesetsky, D. (1982). Paths and Categories. Ph. D. thesis, Massachusetts Institute of Technology.

Pesetsky, D. (1991). Zero syntax: vol. 2: Infinitives. Ms., MIT.

Rawlins, K. (2013). About 'about'. In Proceedings of Semantics and Linguistic Theory (SALT) 23.

Roelofsen, F. (2017). What's wrong with wonder that and believe whether? Presented at University of Konstanz, January 12, 2017.

Roelofsen, F., M. Herbstritt, and M. Aloni (to appear). The *whether puzzle. In E. Onea, K. von Heusinger, and M. Zimmermann (Eds.), Question in Discourse.

Simons, M. (2007). Observations on embedding verbs, evidentiality, and presupposition. Lingua 117(6), 1034-1056.

Spector, B. and P. Egré (2015). A uniform semantics for embedded interrogatives: an answer, not necessarily the answer. Synthese 192(6), 1729-1784.

Stephenson, T. (2007). Judge dependence, epistemic modals, and predicates of personal taste. Linguistics and Philosophy 30(4), 487-525.

Theiler, N., F. Roelofsen, and M. Aloni (2016). A uniform semantics for declarative and interrogative complements. Ms., University of Amsterdam.

Uegaki, W. (2016). Content Nouns and the Semantics of Question-Embedding. Journal of Semantics 33(4), 623-660. 